\title{
Oxygen consumption of the crab Callinectes rathbunae parasitized by the rhizocephalan barnacle Loxothylacus texanus as a function of salinity
}

\author{
Rafael Robles ${ }^{1,2}$, Fernando Alvarez ${ }^{1, *}$, Guillermina Alcaraz ${ }^{3}$ \\ ${ }^{1}$ Colección Nacional de Crustáceos, Instituto de Biología, Universidad Nacional Autónoma de México, \\ Apartado Postal 70-153, 04510 D. F., Mexico \\ ${ }^{2}$ Department of Biology, University of Louisiana, Lafayette, PO Box 42451, Lafayette, Louisiana 70504-2451, USA \\ ${ }^{3}$ Laboratorio de Ecofisiología, Departamento de Biología, Facultad de Ciencias, Universidad Nacional Autónoma \\ de México, Apartado Postal 70-371, 04510 D. F., Mexico
}

\begin{abstract}
Rhizocephalan parasitism is one of the most important biotic factors affecting commercially valuable crab species in families such as Portunidae and Lithodidae. In addition to the long term and permanent effects of this parasitism on the hosts (e.g. sterilization, cessation of growth), other functional problems may arise due to the considerable size of the parasite and to its particular position inside and outside of the host. In this study, experiments with the Mexican blue crab Callinectes rathbunae parasitized by the rhizocephalan barnacle Loxothylacus texanus were conducted in the laboratory to test whether the parasite affects the host's oxygen consumption rate under changing salinity conditions. A total of 83 crabs (49 parasitized and 34 controls), all initially acclimated to a salinity of 5 , were used for metabolic rate measurements over sequential $24 \mathrm{~h}$ periods at salinities of 5, 15 and 25. During this 3 d period, oxygen consumption of individual crabs was measured 5 times per day. Parasitized crabs were classified, according to the degree of maturation of the parasite, as: (1) crabs with internal parasites, bearing a modified abdomen; (2) crabs with virgin, immature, recently emerged parasites; and (3) crabs with mature, fully developed parasites. Crabs with internal and virgin parasites did not show differences in oxygen consumption rates with respect to control crabs. Crabs with mature parasites consumed from 57 to $139 \%$ more than other crabs under all salinity conditions. Although there is a significant metabolic cost for the host associated to the presence of mature $L$. texanus, it is not clear what specific process is responsible for the observed results. Since the increased oxygen consumption was unrelated to salinity, it is concluded that the host's osmoregulatory capabilities are not affected; other possible explanations include the constant grooming and maintenance of the parasite. At the population level, our results suggest that hosts bearing mature parasites may move within the estuaries from low to high salinity areas in order to reduce the metabolic energy expenditure caused by the combination of the parasite and hypoosmotic conditions.
\end{abstract}

KEY WORDS: Oxygen consumption $\cdot$ Callinectes rathbunae $\cdot$ Loxothylacus texanus

\section{INTRODUCTION}

Salinity is one of the dominant environmental factors affecting the metabolism of estuarine organisms (Findley et al. 1978). Organisms living in an environment

${ }^{*}$ Corresponding author. E-mail: falvarez@servidor.unam.mx with fluctuating salinity levels have to cope with substantial ionic and osmotic stress, either through active osmoregulation or by osmoconforming (Péqueux 1995). Callinectes rathbunae is an estuarine crab adapted to withstand large salinity fluctuations occurring in short periods of time. This species has been found to increase its oxygen consumption rate as salinity decreases (Rosas et al. 1986, 1989); nevertheless, it is 
preferentially distributed in the oligohaline sections of estuaries. When parasitized by the rhizocephalan barnacle Loxothylacus texanus, the osmoregulatory response of $C$. rathbunae may be impaired due to the size and position of the parasite which adds to the host an additional unregulated area of exposure to the medium. The morphology of $L$. texanus lacks any apparent structures that could themselves be involved significantly in osmoregulation. The external part of the parasite, known as 'externa', contains the reproductive organs and a mantle cavity that typically opens to the exterior by means of a single mantle orifice (Høeg \& Lützen 1995). It is hypothesized that the parasite may interfere with the osmoregulation of its host because the externa at one end constantly takes in water from the environment, and at the other end the parasite tissues are in direct contact with the internal tissues of the host crab.

Oxygen consumption rates can be used to evaluate the amount of energy an organism is using to maintain a stable concentration of the internal fluids (Findley et al. 1978); however, in this study it is assumed that changes in activity rhythms may also modify the way in which energy is used. Furthermore, we hypothesized that the parasitism by Loxothylacus texanus may reduce the ability of Callinectes rathbunae to adjust to fluctuating environments, causing the host to increase its energy expenditure, which can be measured through the oxygen consumption rate. The existence of a significant effect could explain a differential distribution of parasitized crabs within the estuary, with parasitized crabs occurring preferentially in areas with medium to high salinities.

To test this hypothesis, control and parasitized specimens of Callinectes rathbunae were subjected to abrupt sequential salinity changes over a $3 \mathrm{~d}$ period (from 5 to 15 to $25 \mathrm{ppt}$ ) and the oxygen consumption rate measured 5 times $\mathrm{d}^{-1}$ to account for diel variations. Hosts with different developmental stages of the parasite (internal, virgin or recently emerged, and mature) were included to determine whether all the stages affected the host to the same extent.

\section{MATERIALS AND METHODS}

Parasitized and non-parasitized Callinectes rathbunae were obtained from commercial fishery catches made in Alvarado Lagoon, Veracruz, Mexico. The crabs were transported to the Institute of Biology, Universidad Nacional Autónoma de México (UNAM), in Mexico City, where they arrived within $6 \mathrm{~h}$ of collection. Both parasitized and non-parasitized crabs were acclimated at $28^{\circ} \mathrm{C}$ and a salinity of 5, in holding tanks with a recirculating water system. Initially water was prepared by mixing Alvarado Lagoon water with artificial seawater, but it was gradually changed to $100 \%$ artificial seawater within 4 d of laboratory acclimation. Dissolved oxygen concentration was maintained between 5.4 to $5.8 \mathrm{mg} \mathrm{l}^{-1}$, and a $12: 12 \mathrm{~h}$ day:night photoperiod was established. During each day of the acclimation period, crabs were given fresh fish, non-ingested food and feces were removed, and 30\% of the water was changed. Water temperature, salinity and ammonia levels were recorded twice $\mathrm{d}^{-1}$ (APHA 1985). Organisms were maintained under these conditions for a minimum of $7 \mathrm{~d}$ before they were used in the experiments. Crabs were not fed for $24 \mathrm{~h}$ prior to the experiment to avoid interference from digestive processes.

Parasitized crabs were classified into 4 groups to estimate the effect of the different developmental stages of Loxothylacus texanus on the metabolic response of Callinectes rathbunae. Crabs were sorted according to Reinhard (1950) and Alvarez et al. (1999) as follows: (1) non-parasitized crabs, this group was used as control; (2) crabs bearing an internal parasite, including males with abnormally shaped abdomen and atrophied first pleopods (feminized males), and females presenting atrophied pleopods with mature abdominal shape; (3) crabs with 1 recently emerged, immature, virgin parasite externa; and (4) crabs with 1 mature, fully grown parasite externa.

The experiments were conducted in recirculating water systems, each one composed of 16 individual respirometry chambers of 1.81 capacity. Each system had 2 reservoirs: an inferior one to collect the water coming from the chambers and a superior one where water was aerated to obtain the desired dissolved oxygen concentration before exiting to the chambers; water was pumped from the inferior to the superior reservoir with an immersion pump. Both reservoirs in each system were provided with automatic heaters, protein skimmers and mechanical filters, which maintained appropriate water conditions during the experiment.

Once acclimated, crabs were placed individually in the continuous flow respirometry chambers at $28^{\circ} \mathrm{C}$ and a salinity of 5 . Dissolved oxygen concentration measurements were started after $24 \mathrm{~h}$. In each system, 1 empty chamber was used as a blank control (without crab) to document that no oxygen losses were due to the system design or to undetected bacterial growth. The rate of water flow was regulated to maintain an appropriate oxygen concentration in the chambers ( $>5 \mathrm{mg} \mathrm{O}_{2} \mathrm{l}^{-1}$ ) as well as to provide a measurable difference between dissolved oxygen concentrations, measured before and after passing through the chambers. 
The oxygen consumption rate $\left(M_{\mathrm{O}_{2}}\right)$ was calculated by:

$$
M_{\mathrm{O}_{2}}=\left(\left[\mathrm{O}_{2_{\text {in }}}\right]-\left[\mathrm{O}_{2_{\text {out }}}\right]\right) F
$$

where $\left[\mathrm{O}_{2 \text { in }}\right]$ and $\left[\mathrm{O}_{2 \text { out }}\right]$ are the oxygen concentrations measured in the inflow and outflow water, respectively; and $F$ is water flow rate $\left(\mathrm{h} \mathrm{h}^{-1}\right)$ (Cech 1990). Data were recorded using a dissolved oxygen meter with a polarographic electrode (YSI 50B, Yellow Springs Instruments; $\pm 0.01 \mathrm{mg} \mathrm{l}^{-1}$ ). Oxygen consumption data were corrected by subtracting the oxygen consumption of the blank respirometer if there was any. The oxygen consumption rate is expressed as mg of oxygen consumed $\mathrm{h}^{-1}, \mathrm{~g}^{-1}$ of dry weight $\left(\mathrm{mgO}_{2} \mathrm{~h}^{-1}\right.$ $\mathrm{g}^{-1}$ dry wt).

Oxygen consumption rate was measured for each crab at 15:00,18:00, 21:00, 07:00 and 10:00 h over the course of a day. Once these measurements were taken, water salinity was abruptly increased from 5 to 15 . Oxygen consumption was measured again at the same times. The next day, salinity was increased to 25 and the same measurements were taken. All the salinity changes were done at 11:00 h.

At the end of the experiments, crabs were sacrificed by placing them on ice and the external parasites (virgin or mature) dissected. Both the parasite and crabs' wet weights were obtained, and finally crabs and parasites were dried at $60^{\circ} \mathrm{C}$ for $96 \mathrm{~h}$ to obtain their dry weight.

Because the same animals were followed during the 3 d experiment through the salinity changes, the data obtained were not treated as independent. Therefore, to determine whether there was a significant effect of parasite developmental stage, salinity and time of day on oxygen consumption rates, a Repeated Measures Analysis of Variance (RM-ANOVA) was conducted. The potential effect of the crab's sex was also taken into account. Developmental stage of the parasite and host sex were used as fixed factors, while both salinity level and time of day were used as the repeated measures. Data were examined for normality using visual inspections as well as by conducting a Shapiro-Wilkes test. Where necessary, data were transformed using the Box-Cox power transformation in order to select the most adequate procedure (Sokal \& Rohlf 1995). The assumption of circularity of the variance-covariance matrix was tested with a Mauchly test of sphericity (von Ende 1993). If needed, Huynh-Feldt's adjusted probabilities for $F$ were used (von Ende 1993). After a first inspection, non-significant factors were eliminated from the test and another RM-ANOVA performed.

Upon obtaining significant differences, means were compared using a multiple comparison test (leastsquares means and adjusted Tukey test). All the analyses were conducted with the SAS statistical program (SAS Version 6.12 on UCS, SAS Institute).

\section{RESULTS}

Host oxygen consumption rate did not differ between sexes $\left(F_{1,75}=0.99, \mathrm{p}=0.324\right)$ and there were no significant interactions between parasite developmental stages and host $\operatorname{sex}\left(F_{3,75}=0.94, \mathrm{p}=0.4271\right)$, time of day and host sex $\left(F_{4,150}=0.41, \mathrm{p}=0.782\right)$ or salinity and host sex $\left(F_{2,150}=0.52, \mathrm{p}=0.598\right)$ on oxygen consumption rate. Therefore, a second RM-ANOVA was performed eliminating host sex as a factor.

The matrix differed from circularity for the factors salinity $\left(W=0.912, \chi^{2}=7.21, \mathrm{p}=0.027\right)$ and time of day $\left(W=0.545, \chi^{2}=47.01, \mathrm{p}<0.001\right)$, and for the interaction salinity versus time of day $\left(W=0.127, \chi^{2}=157.34\right.$, $\mathrm{p}<0.001)$. Therefore, we used adjusted probabilities to calculate $F$ for within subject factors. Callinectes rathbunae oxygen consumption rate varied among the developmental stage of the parasite $\left(F_{3,79}=38.29\right.$, $\mathrm{p}=0.0001)$, salinity $\left(F_{2,158}=597.04, \mathrm{p}=0.0001\right)$ and time of day $\left(F_{4,316}=374.63, \mathrm{p}=0.0001\right)$. There was also significant interaction among all the factors (salinityparasitism, $\mathrm{p}=0.0001$; time-parasitism, $\mathrm{p}=0.0004$; salinity-time-parasitism, $\mathrm{p}=0.0001$ ).

\section{Daily variation in oxygen consumption}

In control crabs, a maximum oxygen consumption rate at 18:00 and 21:00 $\mathrm{h}$ and a minimum at 10:00 $\mathrm{h}$ were found in a salinity of 5 . The same pattern was maintained in a salinity of 15, but in 25 no defined pattern was observed. Crabs with internal parasites did not show a defined pattern in any of these 3 salinities. Crabs with virgin parasites resemble the pattern showed by control crabs, while crabs with mature parasites show different maximum and minimum values for each salinity (Fig. 1). These different patterns resulted in significant interactions between developmental stage of the parasite, salinity and time of day $\left(F_{24,632}=3.14, \mathrm{p}=0.0001\right)$.

\section{Effect of the parasite on oxygen consumption}

Oxygen consumption rates of Callinectes rathbunae differed depending on parasite developmental stage $\left(F_{6,158}=7.17, \mathrm{p}=0.0001\right)$. Neither crabs with internal parasites nor with virgin parasites showed significant differences compared with unparasitized control crabs. Crabs with mature parasites had significantly higher oxygen consumption rates than control crabs (Fig. 1). In a salinity of 5, oxygen consumption rates increased by between 57 and $139 \%$ more than controls; in salinities 15 and 25, by between 69 and $113 \%$, and 90 and $136 \%$, respectively. 


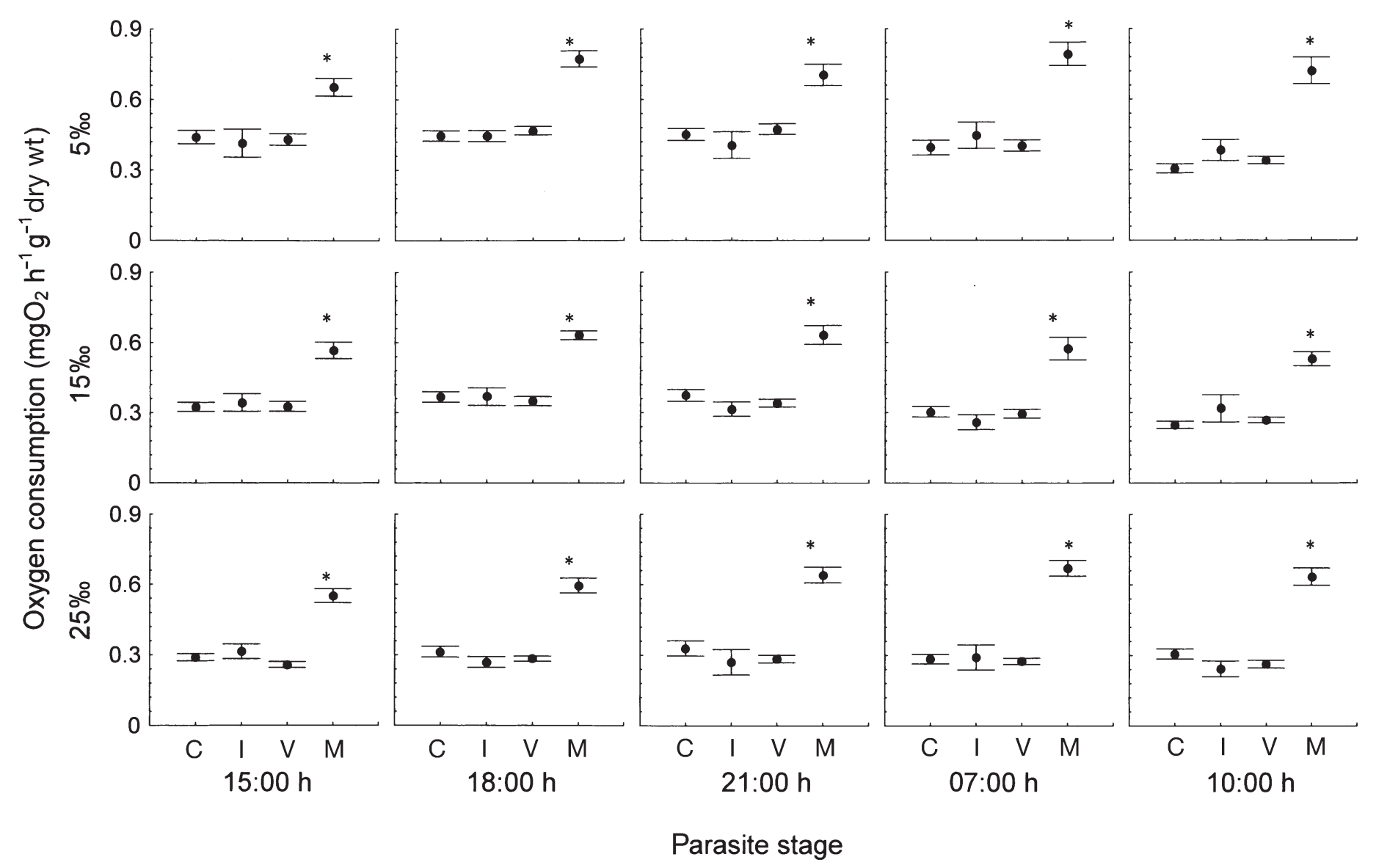

Fig. 1. Diel variation in oxygen consumption of Callinectes rathbunae (mean \pm SE with non-transformed data) in 3 different salinities (C, control crabs; I, crabs with internal parasites; V, crabs with virgin parasites; $M$, crabs with mature parasites). Asterisks denote significantly different values ( $p<0.001$, adjusted Tukey)

\section{Response to salinity changes}

Oxygen consumption rates changed in response to salinity changes. These differences varied among the 3 groups of parasitized crabs $\left(F_{6,158}=7.17, \mathrm{p}=0.0001\right)$. In control crabs, oxygen consumption decreased with increasing salinity; differences ranged from 17 to $26 \%$ when salinity increased from 5 to 15, and from 6 to $14 \%$ when salinity increased from 15 to 25 . Crabs with internal parasites showed significant differences only after salinity was increased from 5 to 15 at 07:00 h. There were no significant differences in respiration rates after salinity was increased from 15 to 25. However, there were significant differences between oxygen consumption rates at a salinity of 25 compared to those at a salinity of 5 . Crabs with virgin parasites and control unparasitized crabs showed similar responses to salinity changes; however, crabs with mature parasites showed a different response to changing salinity. In general, oxygen consumption in this group was almost constant, with 2 values (07:00 and 10:00 h) showing significant differences between salinities of 5 and 15. However, the highest oxygen consumption rate was observed in parasitized crabs exposed to hipoosmotic conditions (Fig. 1).

\section{DISCUSSION}

The present study was conducted to test the hypothesis that the parasitization of Callinectes rathbunae by Loxothylacus texanus represents a significant additional energetic cost for the host crab. Although $C$. rathbunae is an estuarine species with a strong ability to osmoregulate at lower salinity (Rosas et al. 1986), it was expected that parasitized crabs, especially those carrying mature parasites, would be spending more energy than unparasitized ones. We hypothesized that this increase would be due to the maintenance of the parasite mass (interna and externa) and to an in- 
creased osmotic regulation, considering an unregulated flow of water and ions in and out of the host crab through the parasite's externa. We used oxygen consumption as a measurement of the energetic expenses due to the interaction between the parasite infection and water salinity, where the changes in the oxygen consumption were the result of the overall physiological and activity changes induced by the experimental treatments.

The results show that the daily variation in oxygen consumption is small and stable enough to allow for the comparison between control and experimental crabs. There was a general trend for all crabs to consume less oxygen with increasing salinity. Crabs with internal and virgin parasites had similar levels of oxygen consumption to control crabs. Only crabs with mature parasites had significantly higher levels of oxygen consumption than control crabs in all salinites.

There can be several interpretations of these results. The fact that crabs with mature parasites consume significantly more oxygen than the rest could be caused by the following interacting processes. First, the extra energy spent could be used for the maintenance of the parasite's externa, since it is an additional mass which depends on the host crab for all nourishment and external care. Host crabs bearing mature parasites, irrespective of sex, adopt the behavior of ovigerous females who constantly groom the egg mass, incurring another low but constant energy expenditure. However, an egg mass can not be compared in this sense to a mature parasite externa, since the egg mass utilizes oxygen through diffusion from the water on its own and does not require any nourishment. Second, the additional energy spent may be used in osmotic regulation, since the mature parasite can be operating as an open channel that connects the exterior with the host's internal tissues and organs. Parasitized crabs bearing immature externae, which have not developed the mantle opening or an internal space surrounding the gonads, have the same oxygen consumption levels as control crabs. Virgin parasites may remain dormant for extended periods of time if they are not fertilized (Høeg \& Ritchie 1985, Høeg \& Lützen 1995); as a result, energy consumption by the parasite during this period is negligible. Interestingly, crabs with mature parasites consume more oxygen than the rest in all salinities; however, the level of consumption decreases slightly with increasing salinity. Third, the parasite's externa may be consuming oxygen through diffusion, a possibility that was not examined experimentally. The mass of the externa, and consequently its oxygen requirements, may be too small to explain the observed significant differences. The parasite's externa may appear to be a very large structure in relation to the host's size; however, this may be due primarily to its water con- tent. The externae's dry weight ranged from 0.03 to $0.32 \mathrm{~g}$, which represents between 0.55 and $1.65 \%$ of the crab's weight. Under the assumption that the respiratory rate of Loxothylacus texanus is comparable to that of other crustacean species including Callinectes rathbunae, the contribution of the externa to the overall oxygen consumption should be very low. In summary, it is not possible with the available data to identify a single process as responsible for the observed differences.

The implications of the experimental results on the distribution pattern of parasitized Callinectes rathbunae are relevant. It has been documented that $C$. sapidus bearing mature Loxothylacus texanus migrate towards the high salinity areas within the estuary emulating ovigerous females (Adkins 1972, Wardle \& Tirpak 1991). The same migratory behavior has been described for other rhizocephalan-parasitized crab species (Phillips \& Cannon 1978, Lützen 1984). This behavior has been explained for ovigerous C. sapidus as a way of releasing larvae in more favorable sites where dispersal would be enhanced (Williams 1984). In the case of rhizocephalans parasitizing estuarine hosts, this behavior is not completely clear since the larvae, with a brief lecithotrophic development, can be transported outside the estuary, away from susceptible hosts. In any case, no explicit mechanism has been proposed to account for this migratory behavior of either ovigerous females or parasitized individuals. The results presented herein suggest that mature externae of $L$. texanus are energetically costly to host crabs and that consequently, crabs with mature parasites may move to high salinity areas in search of isosmotic conditions and higher partial pressures of dissolved oxygen. Areas with high salinity within estuaries are found near the inlets where water movement produces high partial pressures of dissolved oxygen (Day et al. 1989, Kennish 1991). In contrast, the shallow, stagnant, high temperature and high biomass areas in the upper reaches of estuaries have highly variable and usually low partial pressures of dissolved oxygen, coinciding with low salinity (Day et al. 1989, Kennish 1991).

Finally, another question that emerges is whether the altered migratory behavior of parasitized Callinectes rathbunae has a negative impact on its fishery. Although further field and laboratory studies would be needed to answer this question, it seems probable that as parasite prevalence increases, more parasitized crabs would tend to concentrate close to the inlet areas, leaving the healthy unparasitized fraction in the middle to low salinity areas of the estuary. In this case, the fishery would remove fewer parasitized crabs than if they were randomly distributed. 
Acknowledgements. We are indebted to Dr. Susan Mopper for her suggestions and revision of the statistical analysis and to Dr. Darryl L. Felder for the revision of the manuscript, both of whom are from the University of Louisiana, Lafayette. This study was supported by grants CONACYT 3289P-N and DGAPA-UNAM IN210595 to F.A.

\section{LITERATURE CITED}

Adkins G (1972) Notes on the occurrence and distribution of the rhizocephalan parasite (Loxothylacus texanus Boschma) of blue crabs (Callinectes sapidus Rathbun) in Louisiana estuaries. LA Wildl Fish Comm, Tech Bull 2:1-13

Alvarez F, Gracia A, Robles R, Calderón J (1999) Parasitization of Callinectes rathbunae and Callinectes sapidus by the rhizocephalan barnacle Loxothylacus texanus in southern Veracruz, Mexico. Gulf Res Rep 11:15-21

APHA (American Public Health Association) (1985) Standard methods for examination of water and wastewater, 16th edn. Washington, DC

Cech JJ Jr (1990) Respirometry. In: Shreck CB, Moyle PB (eds) Methods for fish biology. American Fisheries Society, Maryland, p 335-362

Day JW Jr, Hall CAS, Kemp WM, Yáñez-Arancibia A (1989) Estuarine ecology. John Wiley-Liss, New York

Findley AM, Belisle BW, Stickle WB (1978) Effects of salinity fluctuations on respiration rate of oyster drill Thais haemastoma and the blue crab Callinectes sapidus. Mar Biol 49: 59-67

Høeg JT, Lützen J (1995) Life cycle and reproduction in the Cirripedia Rhizocephala. Oceanogr Mar Biol Annu Rev 33: 427-485

Høeg JT, Ritchie LE (1985) Male cypris settlement and its effects on juvenile development in Lernaeodiscus porcellanae Müller (Crustacea: Cirripedia: Rhizocephala). J Exp Mar Biol Ecol 87:1-11

Editorial responsibility: Otto Kinne (Editor), Oldendorf/Luhe, Germany
Kennish MJ (1991) Ecology of estuaries: anthropogenic effects. CRC Press, Boca Raton, FL

Lützen J (1984) Growth, reproduction, and life span in Sacculina carcini Thompson (Cirripedia: Rhizocephala) in the Isefjord, Denmark. Sarsia 69:91-106

Péqueux A (1995) Osmotic regulation in crustaceans. J Crustac Biol 15:1-60

Phillips WJ, Cannon LRG (1978) Ecological observations on the comercial sand crab, Portunus pelagicus (L.), and its parasite, Sacculina granifera Boschma, 1973 (Cirripedia: Rhizocephala). J Fish Dis 1:137-149

Reinhard EG (1950) An analysis of the effects of a sacculinid parasite on the external morphology of Callinectes sapidus Rathbun. Biol Bull 8:277-288

Rosas C, Lázaro-Chávez E, Gómez-Aguirre S (1986) Efecto de las variaciones de salinidad sobre la tasa respiratoria de dos especies de jaibas: Callinectes sapidus y Callinectes rathbunae, en la laguna de Tamiahua, Veracruz, México. Rev Invest Mar 7:71-78

Rosas C, Barrera G, Lázaro-Chávez E (1989) Efecto de las variaciones de salinidad y de la temperatura estacional sobre el consumo de oxígeno de Callinectes rathbunae, Contreras y Callinectes similis (Crustacea: Portunidae). Trop Ecol 30:193-204

Sokal RR, Rohlf FJ (1995) Biometry, 3rd edn. WH Freeman and $\mathrm{Co}$, New York

von Ende CN (1993) Repeated measures analysis: growth and other time dependent measures. In: Scheiner SM, Gurevich J (eds) Design and analysis of ecological experiments. Chapman \& Hall, New York, p 113-137

Wardle WJ, Tirpak AJ (1991) Occurrence and distribution of an outbreak of infection of Loxothylacus texanus (Rhizocephala) in blue crabs in Galveston Bay, Texas, with special reference to size and coloration of the parasite's external reproductive structures. J Crustac Biol 11:533-560

Williams AB (1984) Shrimps, lobsters, and crabs of the Atlantic coast of the eastern United States, Maine to Florida. Smithsonian Institution Press, Washington, DC

Submitted: March 16, 2001; Accepted: January 29, 2002

Proofs received from author(s): May 14, 2002 